RESEARCH ARTICLE

\title{
Attitude of agricultural students towards agricultural entrepreneurship
}

\author{
Jayasudha.$^{1}$, Shantha Sheela.M ${ }^{2}$ \\ ${ }^{1}$ M.Sc Agricultural Extension and Communication, Department of Agricultural Extension and Rural Sociology, TNAU, Coimbatore . \\ ${ }^{2}$ Associate Professor (Agricultural Extension), Directorate of AgriBusiness Development, TNAU, Coimbatore.
}

\begin{abstract}
Entrepreneurs are people who realize new opportunities and channelize effort in the proper direction. Now a days the employment opportunities for agricultural professionals in the public sector are shrinking. Rising unemployment among agricultural graduates and market forces made entrepreneurship a best career for the students. To create self-employment opportunities for unemployed agricultural graduates, entrepreneurship is widely regarded as an integral player. Career aspirations and opportunities for agriculture students are usually with in private and public sector jobs. Initiation to become an entrepreneur or to start up agri business among the student community is rare. Inspite of the blooming opportunities available in agri entrepreneurship sector, students may be reluctant to start agri ventures due to some constraints or hesitations. Thus, this study was carried out primarily to understand the attitude of students towards agripreneurship and factors affecting the motivation of students to become an agripreneur among the final year students of B.Sc (Agri) in Tamil Nadu Agricultural University Coimbatore campus. This study showed that majority of the students had a favorable attitude towards agricultural entrepreneurship.
\end{abstract}

Keywords: Agripreneurs ; Opportunities; Attitude; Employment.

\section{INTRODUCTION}

Entrepreneur is one who is endowed with more than average capacities in the task of organizing and coordinating the factors of production, i.e. land, labor capital and enterprises. Entrepreneur is a person of telescopic faculty drive and talent who perceives business opportunities and promptly seizes them for exploitation. Entrepreneurs and entrepreneurship are arguably the pillars on which economic health of societies was built. Their role has been highlighted in opportunity creation through new ventures and maintenance of existing ones (Evans, 1942).India has the third- largest pool of technical and scientific personnel in the world. However, we cannot utilize its full potential and on the other hand, there is surplus technical manpower that are unemployed. This large pool of technical human resources can be best utilized for developing small-scale industries in the hi-tech areas using improved technologies and scientific methods of production. There are so many agricultural graduates passing from different universities all over India. However there is a corresponding lack of employment opportunities for agricultural professionals in the public sector. For this unemployment, agricultural entrepreneurship is a golden opportunity for them to take it as a career. There are scope in establishing enterprises such as poultry, dairy, fishery, horticulture, food processing , value addition, nursery development, polyhouse etc. The government of India is also supporting these startups with programs like Skill India, Start Up India, Micro Units Development \& Refinance Agency Ltd to Agriclinics and Agri Business Centres scheme and Udaan to help budding entrepreneurs to start and scale new ventures. However only few a students wanted to become entrepreneurs. Career planning is most important in everyones life. It depends on so many factors to decide their goal. A study by Mehta et al. (2011) revealed that for agriculture collegian civil/ administrative jobs remained the first choice followed by educational and research institutional jobs, state government jobs, agro-based public sector, agro-based private sector and self-employment, while, general jobs and farming were the least preferred job areas. Attitudes are defined by cognitive psychology as the predisposition to respond in a generally favorable or unfavorable manner concerning the object of the attitude. The attitudinal approach has been utilized in many fields including evaluating entrepreneurship education. It revealed the mindset of the students

$107 \mid 10-12$ | 1 
towards agricultural entrepreneurship whether they are positive or negative. Hence the present study has been attempted with objectives to

1. Study the demographic characteristic of the students and to

2. Study the attitude of agricultural students towards agricultural entrepreneurship.

\section{MATERIAL AND METHODS}

\section{Sampling and Sampling method:}

A total of 130 final year B.Sc. (Agriculture) of Tamil Nadu Agricultural University, Coimbatore were purposively selected for the study. Because they had undergone entrepreneurship courses and had agroindustry internship programmes during their studies. Moreover, they had better knowledge of entrepreneurship and they were in the stage to decide their career. The interview schedule developed in google form had been sent to all the students and 80 had responded.

For measuring the attitude, the attitude scale developed by Chamela Bai (2016) was used with slight modification based on the study. The scale consists of 14 statements. To measure the attitude of agriculture graduates towards agripreneurship, a five-point continuum was used. The scores assigned for the positive statements were, 5 for strongly agree, 4 for agree, 3 for uncertain, 2 for disagree and 1 for strongly disagree. The scoring for the negative statement was reverse..

The collected data were analyzed using statistical tools viz percentage method, mean score to study the demographic characteristics and attitude of the students.

Table : 1 Demographic characteristic of the students:

$(\mathrm{n}=80)$

\begin{tabular}{|c|c|c|c|}
\hline Variable & Category & No & $\%$ \\
\hline \multirow[t]{2}{*}{ Gender } & Male & 28 & 35.0 \\
\hline & Female & 52 & 65.0 \\
\hline \multirow[t]{3}{*}{ Locality } & Rural & 40 & 50.0 \\
\hline & Semi urban & 21 & 26.2 \\
\hline & Urban & 19 & 23.8 \\
\hline \multirow[t]{5}{*}{ Parents occupation } & Business & 12 & 15.0 \\
\hline & Teacher & 13 & 16.3 \\
\hline & Civil servant & 8 & 10.0 \\
\hline & Farmer & 38 & 47.5 \\
\hline & Others & 9 & 11.2 \\
\hline \multirow[t]{4}{*}{ Annual family income } & Less than 1 lakh & 53 & 66.2 \\
\hline & Between 1 lakh to 2 lakhs. & 7 & 8.80 \\
\hline & Between 2 lakhs to 3 lakhs. & 2 & 2.50 \\
\hline & Above 3 lakhs. & 18 & 22.5 \\
\hline \multirow[t]{2}{*}{ Family type } & Nuclear family & 69 & 86.3 \\
\hline & Joint family & 11 & 13.7 \\
\hline \multirow[t]{5}{*}{ Size of land holding } & Land less & 19 & 23.8 \\
\hline & Marginal & 32 & 40.0 \\
\hline & Small & 19 & 23.8 \\
\hline & Medium & 6 & 7.40 \\
\hline & Big & 4 & 5.00 \\
\hline \multirow[t]{4}{*}{ Academic perfomance (OGPA) } & $6.0-7.0$ & 0 & 0.00 \\
\hline & $7.1-8.0$ & 32 & 40.0 \\
\hline & $8.1-9.0$ & 48 & 60.0 \\
\hline & $9.1-10.0$ & 0 & 0.00 \\
\hline \multirow[t]{2}{*}{ Entrepreneurship workshop } & Yes & 30 & 37.5 \\
\hline & No & 50 & 62.5 \\
\hline
\end{tabular}

$107|10-12| 2$ 


\section{RESULTS AND DISCUSSION}

\section{Demographic characteristic of the students :}

It was observed from the Table. 1, that majority of the student respondents were female (65.0\%). Generally the risk-taking ability was more in males compared to females. Half of the respondents came from a rural background (50.0\%) which made them more interest towards agripreneurship and they had basic knowledge about agriculture. Nearly half of the respondents had parents predominant occupation as farming (47.5\%) followed by teaching profession (16.3\%).

About three fourth of the parents annual income was less than one lakh (66.2\%), so the respondents perceived that their main constraints were the financial investment in the business. Majority of them were from the family (86.3\%). This also might be a reason that respondents fear that if they fail, nobody in their family would support financially and psychologically.

Mostly the respondent's parents had marginal size of land holding (40.0\%) and this revealed that investment on land for agristartups might be reduced. Sixty percent of the students had OGPA ranged between 8.1 to 9.0 and three fourths of the students had not undergone entrepreneurship workshop (62.5\%).

Table : 2 Attitude of agricultural students towards agripreneurs.

$(n=80)$

\begin{tabular}{|c|c|c|}
\hline Statements & Mean Score & Rank \\
\hline $\begin{array}{l}\text { Agricultural graduates have better conditions for entrepreneurship compared with other } \\
\text { graduates. }\end{array}$ & 4.42 & I \\
\hline Agricultural graduates have necessary skills for entrepreneurship & 4.41 & II \\
\hline There is potential for the agricultural based entrepreneurship in India & 4.38 & III \\
\hline $\begin{array}{l}\text { Lack of employment opportunities in the public sector has doubled necessity of } \\
\text { entrepreneurship }\end{array}$ & 4.26 & IV \\
\hline Agricultural entrepreneurship requires a measured vision and mission. & 4.21 & V \\
\hline Agricultural entrepreneurship is the right career choice for the younger generation & 4.20 & $\mathrm{VI}$ \\
\hline $\begin{array}{l}\text { An agri-clinic or agri-business training can create confidence to accept agricultural } \\
\text { entrepreneurship as a profession }\end{array}$ & 4.16 & VII \\
\hline Agricultural entrepreneurship should be given top priority for development & 4.07 & VIII \\
\hline Agricultural entrepreneurship does not help in developing good personality & 3.90 & IX \\
\hline Agricultural graduate can earn more than other professional graduates & 3.73 & $\mathrm{x}$ \\
\hline Agricultural entrepreneurship doesn't provide good employment opportunity & 3.66 & $\mathrm{XI}$ \\
\hline Agricultural entrepreneurship has easy market access. & 3.52 & XII \\
\hline Agricultural entrepreneurship does not provide maximum net profit and income. & 3.48 & XIII \\
\hline Entrepreneurship in agriculture is more difficult than other sectors. & 2.67 & XIV \\
\hline
\end{tabular}

The Mean score was calculated by dividing the total scores given by all the respondents to the statement by the total number of respondents. Based on the mean score value, the ranking was given. Most of the student respondents had expressed that agricultural graduates had better conditions for entrepreneurship compared with other graduates (4.42) and they had knowledge on the basics of agriculture, processing and necessary skills for entrepreneurship (4.41). They also stated that there was a huge potential for the agricultural- based enterprises in India (4.38) and the lack of employment opportunities in the public sector has doubled the necessity of entrepreneurship (4.26). They also revealed that agricultural entrepreneurship requires a measured vision and mission (4.21) and agripreneurship was the right career choice for the younger generation
(4.20). Their confidence level would be increased by attending an agri - clinic or agri-business training (4.16). Some of the respondents gave negative opinion such as agricultural entrepreneurship does not help in developing a good personality (3.90), doesn't provide revenue opportunity (3.66) and entrepreneurship in agriculture was more difficult than other sectors (2.67).

Table: 3 Distribution of agriculture graduates based on their attitude towards agripreneurs

\begin{tabular}{lrr} 
& \multicolumn{3}{c}{$(\mathrm{n}=80)$} \\
\hline Category & No & $\%$ \\
\hline Less favourable (Below 52.94 scores) & 12 & 15.0 \\
Favourable (From 52.94 - 64.4 scores) & 53 & 66.3 \\
More favourable (Above 64.4 score) & 15 & 18.7 \\
\hline
\end{tabular}


From the above Table 3, it was observed that the majority of the students had a favourable attitude towards agricultural entrepreneurship (66.3\%) whereas only some of the students $(18.7 \%)$ had a more favorable attitude towards agricultural entrepreneurship followed by 15.00 per cent of students had less favorable attitude towards agricultural entrepreneurship. This finding is in line with the findings of Chamela Bai (2016) who stated that 72.00 per cent of the male students and female (60.0\%) among female agriculture graduates had favourable attitude towards agricultural entrepreneurship, whereas only 3.00 per cent male agriculture graduates and 9.00 per cent female agriculture graduates had most favourable attitude and equal percentage of male and female agricultural graduates (22.00\%) had less favourable attitude towards agricultural entrepreneurship. Also, Dilip Kumar (2017) in his study revealed that out of the overall level of attitude towards agricultural entrepreneurship of the respondents, the majority of the respondents $(57.73 \%)$ had a moderately favourable attitude towards agricultural entrepreneurship, followed by 29.56 per cent who had less favorable attitude, while only 12.71 per cent of the respondents had favorable attitude towards agricultural entrepreneurship. Fluctuating income and uncertainty nature of agriculture was the major

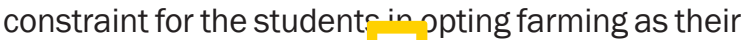
profession (Dayalan, et.a $\overline{\text { Tn }} 18)$.

It could be clearly interpreted from the present study that, majority of the students who were from rural backgrounds had knowledge of agriculture and their parents with marginal size of land holding showed favourable attitude towards agripreneurship. Also it is observed that agricultural graduates had better conditions for entrepreneurship than other graduates and had the necessary skills for entrepreneurship and vast potential for the agriculture-based entrepreneurship in India.

\section{CONCLUSION}

This study concluded that the majority of the agricultural students had a favorable attitude towards agripreneurship. Because agricultural graduates had better conditions for entrepreneurship when compared to other graduates, there were lots of potential for the agricultural-based entrepreneurship in India and also lack of employment opportunities in the public sector had doubled the necessity for entrepreneurship. As per the statement, self-help is the best help : entrepreneurship was the best solution for unemployment in the country. Though entrepreneurship was a blooming opportunity in agriculture, some risks and uncertainity accustomed to starting up in agribusiness. Moreover it is necessary that the government should impose some policies to protect young entrepreneurs from the risk of business losses, especially for on-farm businesses. It may provide belief and protection to overcome their constraints. It has been better and proven that those who had undergone various entrepreneurship programmes and hands-on workshops by agribusiness practitioners during the college days might have increased their confidence to become entrepreneurs.

\section{REFERENCES}

Chamela Bai. (2016). Attitude of Agriculture Graduates of S.K.N. College of Agriculture, towards Agriculture Entrepreneurship. Unpublished Master's thesis. Sri Karan Narendra Agriculture University, Jobner.

Dayalan, S. K., Devarani, L.,Singh, R.J. \& Feroze ,S.M. (2018). Attitude of Agriculture Collegian towards Opting Farming as a Profession.Indian Journal of Extension Education, 54 (3), 42-47.

Dilip Kumar. (2017). A study on entrepreneurial behaviour among the students at Indira Gandhi Krishi Vishwavidyalaya, Raipur in Chhattisgarh. Unpublished Doctorate's thesis. Indira Gandhi Krishi Vishwavidyalaya, Raipur.

Evans, Jr. G. H. (1942). A theory of entrepreneurship. J. Econ. Hist., 2 : 142-146.

Mehta, S.K., Godara, A.K., Shivrain, D.K. \& Singh, N.(2011). The Perceived Preferences and Priority Pattern of Farm Graduates towards Higher Agricultural Education Vis-À-Vis Employment, Journal of Social Sciences, 27(3): 201-208. 